\title{
Heat Shock Stimulate Division of Hypocotyle Suspension Culture of Dianthus caryophyllus L.
}

\author{
Sahla Mohamed Zeadan \\ Dept. of Biol. College of Education University of Mosul - IRAQ.

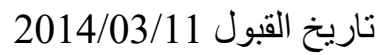 \\ 2013/09/24 تاريخ الاستلام
}

\section{الخلاصة}

نجحت الدراسة الحالية في إنثاء مزارع المعلقات الخلوية المشتقة من السيقان تحت الفلقية لبادرات

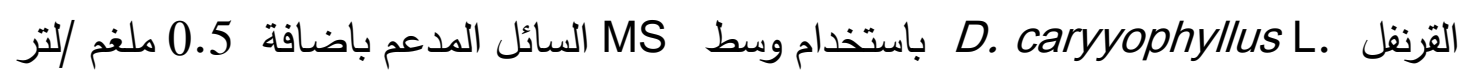

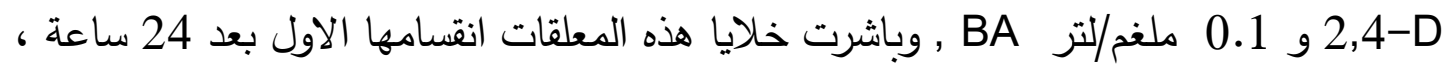

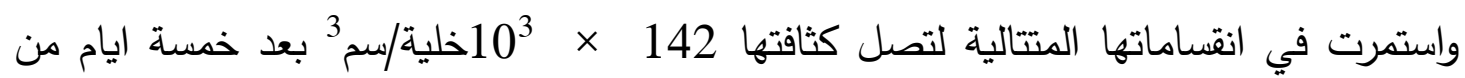
تحضينها، واعتمد في هذه الدراسة تعريض مزارع المعلقات الخلوية قبل زراعتها الى درجات حرارية

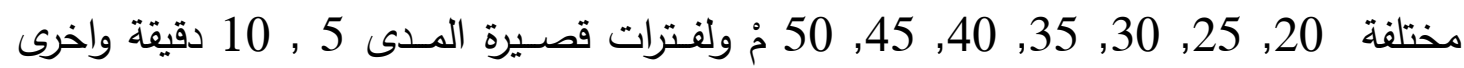

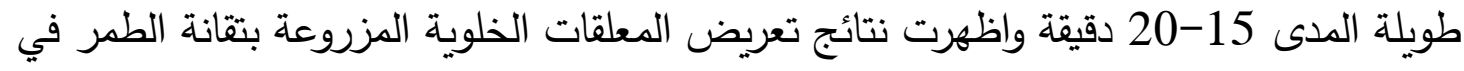

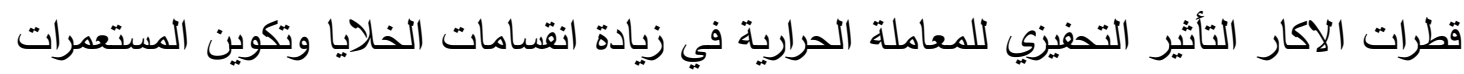
الخلوية لتصل إلى 959مستعمرة عند تعرضها للمعاملة الحرارية قصيرة المدى $35^{\circ} \mathrm{C} / 5 /$ min واتصف الكالس بلونه الاخضر وبنيته الهثة.

\section{Abstract}

The study succeeded in establishing a fine cell suspension derived from callus of carnation, Dianthus caryophyllus L. Hypocotyle explants in liquid MS medium supplemented with $0.5 \mathrm{mgL}^{-1} \quad 2,4-\mathrm{D}$ and 0.1 $\mathrm{mgL}^{-1} \mathrm{BA}$. The cells begin its first division within $24 \mathrm{~h}$. These cell were continued their subsequent divisions to produce $142 \times 10^{3}$ cell $/ \mathrm{ml}$ culture after five days of initiation. Results indicated that exposure of cell suspension to $20,25,30,35,40,45$, and $50^{\circ} \mathrm{C}$ short-term $5,10 \mathrm{~min}$. and long-term 15-20 min. stimulate the division of cells suspension in all treatments. Heat shock sustained the division of cell cultured in multiple drop array (MDA) technique and increase the formation of cellular colonies which produced a numerous of calli primordia. The total number 
of colonies was 959 developed when cells exposed to with the short-term $35^{\circ} \mathrm{C} / 5$ min heat shock. The produced calli was green in colour and friable in texture.

\section{Introduction}

Many studies reported that heat treatment have positive effects on different plant since it stimulate synthesis of novel protein named heat shock protein (HSP). Moreover, heat shock accelerate oxidation processes and help in some enzymes production (1). The same effect occur in yeast (2), and pathogenic fungi (3). Other investigators found that heat shock treatment increase the elasticity of plant cell wall and protein synthesis in cell cytoplasm of maize plant (4) and cucumber (5). Such study explained that exposure of plant cells to $45 \mathrm{oC}$ for one minute increase calcium ion $\mathrm{Ca}+2$ in cell coupled with increasing building up phosphate lipids (6). In Lycopersicon peruvianum L. Heat shock stimulates synthesis of proteins and forming granular aggregates in cytoplasm of tomato culture (7). Other study observed that exposure of cell suspension of Helianthus annuus L. to $40 \mathrm{oC}$ for 10 minute promoted the division of cells as well as increased the production of cellular colonies after days of culture (8).

A study indicated that exposure of cell suspension of Medicago sativa to low temperature decrease the uptake of ion and soluble molecules in cells which resulted hardness of cell wall $(9,10)$ they reported that exposure of cell suspension of Lycopersicon esculentum to $35 \mathrm{oC}$ for 5 minute, result in a rapid and reversible decline of study level and mitotic index. The aim of this study is to recognize the effect of heat shock in division of cell suspension and their development to primordia of callus.

\section{Materials and methods}

* Production of axenic seedlings:

Surface sterilized seeds of carnation, Dianthus caryophyllus var. G.J. Sim were cultivated on the surface of $25 \mathrm{ml}$ of agar-solidified MS medium (11) at ratio of there seeds/flask. They were kept in culture room in dark for 3 days and after germination they transferred to light/dark regime and light intensity of 3000 Lux. Three weeks old axenic seedlings were utilized for hypocotyle explants.

\section{* Establishment of cell suspension culture:}

Hypocotyles explants were cultured on the surface of agar solidified MS medium either supplied with the addition of $0.5 \mathrm{mgL}-1$ 2,4$\mathrm{D}$ and $0.1 \mathrm{mgL}-1 \mathrm{BA}(12)$ or with $1.0 \mathrm{mgL}-1 \mathrm{IAA}$ and $1.0 \mathrm{mgL}-1$ kinetin 
(13) for callus initiation. One gram pieces of friable and young hypocotyle calli were placed in $50 \mathrm{ml}$ of the liquid culture medium MS $+0.5 \mathrm{mgL}-1$ 2,4-D and $0.1 \mathrm{mgL}-1 \mathrm{BA}$ using $100 \mathrm{ml}$ volume conical flasks. They were kept in rotary shaker (Shaking incubator. New Bruniswic U.S.A.) at velocity of $150 \mathrm{rpm}, 28 \pm 2 \mathrm{oC}$ in dark. The cultures were passed through sterile plastic sieve of $46 \square \mathrm{m}$ pores (PGM.G, U.K.) which allow only the passage of fine cells (14). The cultures were kept in the previous condition. These suspensions were regularly sub-cultured every four days by removing the medium and replaced with same volume of fresh prepared medium.

\title{
* Viability and density of cell suspension determination:
}

Viability of cell suspension was carried out by mixing $0.1 \mathrm{ml}$ of Evan blue solution (Chemical Ltd., Poole, England) with $1.0 \mathrm{ml}$ sample of cell suspension and examined microscopically (15).

This following formula was used to calculate the percent of viable cells

\author{
Total number of viable cells \\ $\%$ viability $=$ \\ Total number of cell
}

Determination of cell suspension density was performed (17) by taking $0.1 \mathrm{ml}$ samples from culture after 24, 48, 72, 96, 120, 144 and 168 h. of incubation. Cells were counted in each sample of each interval by heamocytometer (Labsco, W. Germany).

\section{* Exposure of cell suspension to heat shock:}

Samples of $1.0 \mathrm{ml}$ of cell suspension were taken at density of $1.42 \times 103 \mathrm{cell} / \mathrm{ml}$ and placed into $5.0 \mathrm{~cm}$ capacity sterile test tube. These samples were exposed to various temperature including 20, 25, 30, 35, 40, 45 , and $50 \mathrm{oC}$ for 5.0 and $10 \mathrm{~min} /$ each to represents the short-term heat shock. Other samples were heat-treated using the same degrees but for 15 and $20 \mathrm{~min} /$ each representing the long-term heat shock. Each sample was treated by soaking the test tube into water bath previously fixed on the desired temperature for $10 \mathrm{~min}$, then tubes were removed and immersed into ice bath to bring the degree to room temperature. After treatment all samples are ready for culture (18). 
* Culture of cell suspension by multiple drop array technique:

All cell suspensions of $1.0 \mathrm{ml}$ volume heat-treated and untreated were cultured by embedding in agar (19). The procedure involved the mixing of $1.0 \mathrm{ml}$ of cell suspension with $1.0 \mathrm{ml}$ of $3 \%$ agar autoclaved and molten solution kept in water bath at $40 \mathrm{oC}$, The produced mixture was dripped into identical drops on the bottom of $9.0 \mathrm{~cm}$ diam. Plastic Petridish (Sterilin, UK) at ratio of 8 drops/dish. They kept open in the cabinet for solidification, then $5.0 \mathrm{ml}$ of fresh liquid MS medium which used in the establishment of cell suspension was added to each dish. Lids were put and dishes closed by nescofilm. The specimens kept in culture room at condition of 25oC, 700-500 diffused illumination $16 \mathrm{~h}$ and $8 \mathrm{~h}$ dark. Cells cultured in drop were examined microscopically every day to detect their divisions. These cultures were subcultured every four days by removing the liquid medium and replaced with the same volume of fresh medium.

\section{* Development and transfer callus primordia:}

After a series of cell divisions numbers of small size callus primordia were developed into the agar drops. These small size primordia were picked up (20) and transferred to $100 \mathrm{ml}$ vial containing $25 \mathrm{ml}$ of agar - solidified MS medium supplemented with $0.5 \mathrm{mgL}-1$ 2,4-D and $0.1 \mathrm{mgL}-$ $1 \mathrm{BA}$ which used for callus initiation. Specimens were kept in culture room at the same condition explained above.

\section{Results}

\section{* Initiation of cell suspension from hypocotyle calli:}

The results expressed that the friable callus induced on agarsolidified MS medium provided with $0.5 \mathrm{mgL}-1$ 2,4-D and $0.1 \mathrm{mgL}-1 \mathrm{BA}$ (Fig. 1,A) was suitable to produce fine and homogenize cell suspension. Growth of these culture continued their division producing high densities of viable cells (Table 1).

Table (1) : Density and viability of cells forming suspension culture derived from hypocotyle of Dianthus caryophyllus $\mathbf{L}$.

\begin{tabular}{|c|c|c|}
\hline $\begin{array}{c}\text { Incubation } \\
\text { period (h) }\end{array}$ & $\begin{array}{c}\text { Cell density } \\
\left(\mathbf{x 1 0}^{\mathbf{3}} \text { cells }\right)\end{array}$ & $\begin{array}{c}\text { Cell viability } \\
(\mathbf{\%})\end{array}$ \\
\hline 24 & 46 & 55 \\
\hline 48 & 60 & 60 \\
\hline 72 & 80 & 76 \\
\hline 96 & 116 & 86 \\
\hline 120 & 142 & 87 \\
\hline 144 & 125 & 80 \\
\hline 168 & 90 & 72 \\
\hline
\end{tabular}


* Culture of heat-pretreated cell suspension in agar drop :

Preliminary experiment showed that the density $142 \times 103$ cell $/ \mathrm{ml}$ is the most convenient to culture. Samples of cell suspension, pretreated with temperature of short-term and subsequently embedded in agar showed that most cells still alive and starting their first division after the third day of culture forming two daughter cells (Fig.1.B). The second division occur after $24 \mathrm{~h}$ from the first division to produce four cells stage (Fig.1.C). On the other word, these cell tolerated these degrees of temperature, since they continuing division producing cell colonies within 14 days (Fig. 1.D). The total number of colonies was 959 (Table 2) and formation of callus primordia involved 21 day. But they varied in their effects on the numbers of colonies and calli primordia. Most of callus primordia developed within 10-14 day after culture having the green colour but they differ in their sizes (Fig. 1.E).

Table (2): Effect of short-term heat shock on division of cell suspension of Dianthus caryophyllus and development of callus primordia.

\begin{tabular}{|c|c|c|c|c|}
\hline $\begin{array}{l}\text { treatment } \\
{ }^{\circ} \mathrm{C} / \mathrm{min}\end{array}$ & $\begin{array}{l}\text { First div. } \\
\text { (d) }\end{array}$ & $\begin{array}{c}\text { Formation of } \\
\text { CC } \\
\text { (d) }\end{array}$ & $\begin{array}{c}\text { Development } \\
\text { of CP }\end{array}$ & $\begin{array}{c}\text { Number } \\
\text { CP }\end{array}$ \\
\hline $\begin{array}{l}\text { Untreated } \\
\text { (control) }\end{array}$ & 6 & 102 & 56 & 6 \\
\hline $20 / 5$ & 4 & 236 & 49 & 10 \\
\hline$/ 10$ & 4 & 365 & 84 & 10 \\
\hline $25 / 5$ & 4 & 348 & 149 & 17 \\
\hline$/ 10$ & 4 & 242 & 174 & 19 \\
\hline $30 / 5$ & 4 & 711 & 511 & 22 \\
\hline$/ 10$ & 4 & 478 & 363 & 21 \\
\hline $35 / 5$ & 3 & 959 & 805 & 30 \\
\hline$/ 10$ & 3 & 745 & 465 & 29 \\
\hline $40 / 5$ & 4 & 227 & 182 & 11 \\
\hline$/ 10$ & 4 & 265 & 207 & 13 \\
\hline $45 / 5$ & 4 & 655 & 324 & 26 \\
\hline$/ 10$ & 5 & 419 & 301 & 12 \\
\hline $50 / 5$ & 5 & 104 & 85 & 12 \\
\hline$/ 10$ & 5 & 98 & 54 & 10 \\
\hline
\end{tabular}

The results also observed that long-term heat shock enhanced cell division within 3-4 days, cells continued their division to form cellular colonies within 2 weeks from culture. The total number of colonies reached 518 (Table 3) when cell suspension treated with long-tem $35 \mathrm{C}^{0} / 15 \mathrm{~min}$ heat shock. These colonies developed to form numerous of 
calli primordia within 25 days, the produced calli were dark green in color and compact in texture. (Fig. 1.F)

Table (3): Effect of long-term heat shock on division of cell suspension of Dianthus caryophyllus and development of callus primordia.

\begin{tabular}{|c|c|c|c|c|}
\hline $\begin{array}{c}\text { Heat } \\
\text { treatment } \\
\text { oC/min }\end{array}$ & $\begin{array}{c}\text { First div. } \\
\text { (d) }\end{array}$ & $\begin{array}{c}\text { Formation of } \\
\mathbf{C C} \\
(\mathbf{d})\end{array}$ & $\begin{array}{c}\text { Development } \\
\text { of CP }\end{array}$ & $\begin{array}{c}\text { Number } \\
\text { CP }\end{array}$ \\
\hline $\begin{array}{c}\text { Untreated } \\
\text { (control) }\end{array}$ & 7 & 211 & 215 & 17 \\
\hline $20 / 15$ & 3 & 180 & 135 & 14 \\
\hline$/ 20$ & 3 & 255 & 163 & 16 \\
\hline $25 / 15$ & 3 & 274 & 207 & 15 \\
\hline$/ 20$ & 3 & 262 & 192 & 11 \\
\hline $30 / 15$ & 4 & 425 & 234 & 20 \\
\hline$/ 20$ & 4 & 350 & 290 & 17 \\
\hline $35 / 15$ & 3 & 518 & 322 & 13 \\
\hline$/ 20$ & 3 & 365 & 215 & 20 \\
\hline $40 / 15$ & 4 & 178 & 95 & 17 \\
\hline$/ 20$ & 4 & 122 & 65 & 13 \\
\hline $45 / 15$ & 4 & 248 & 161 & 14 \\
\hline$/ 20$ & 4 & 185 & 155 & 17 \\
\hline $50 / 15$ & 4 & 86 & 60 & 12 \\
\hline$/ 20$ & 4 & 70 & 55 & 12 \\
\hline
\end{tabular}

CC: Cellular Colony ,CP: Callus Primordia 
Heat Shock Stimulate Division of Hypocotyle Suspension Culture of Dianthus ...

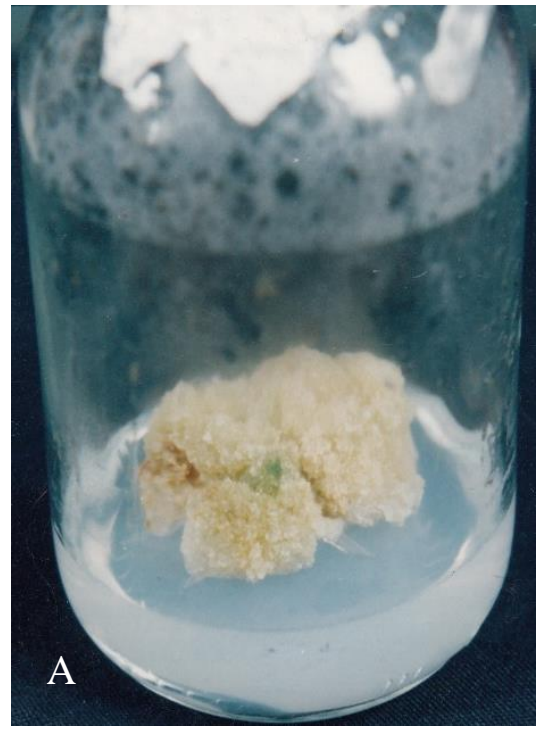

Callus of hypocotye age 3 weeks

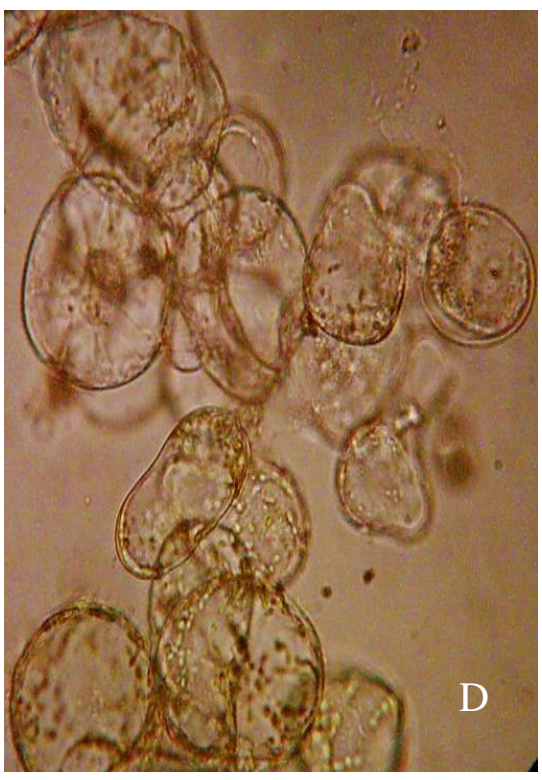

Cellular colonies

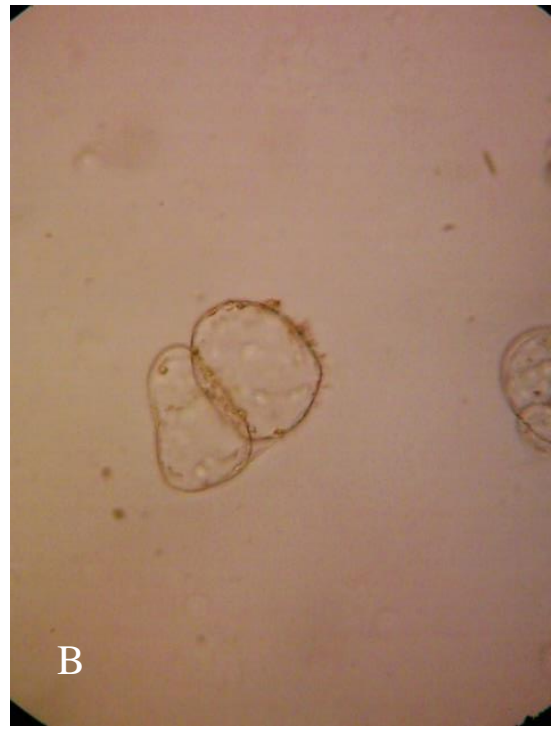

Two daughter cells

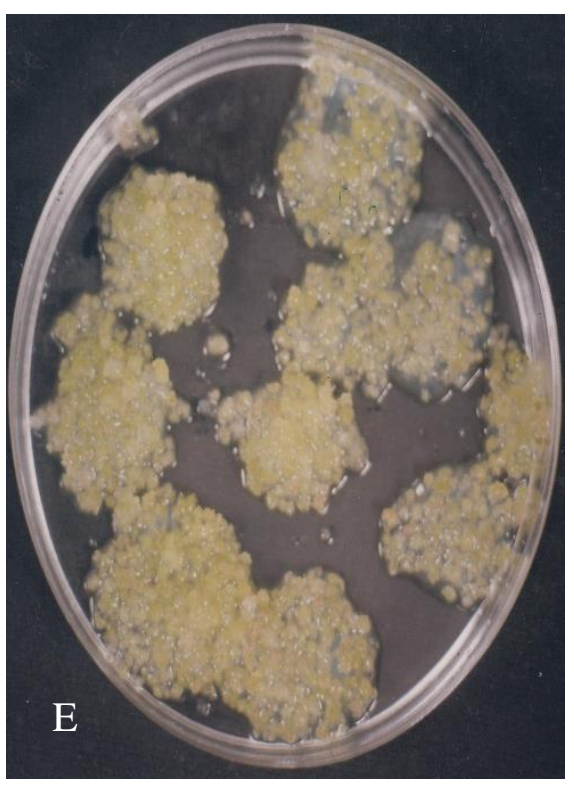

Callus from short term $35^{\circ} \mathrm{C} / 5 \mathrm{~min}$

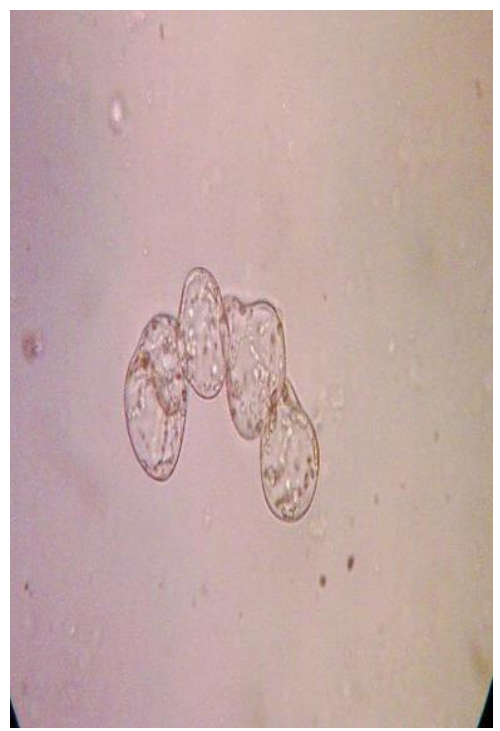

4 cells-stage

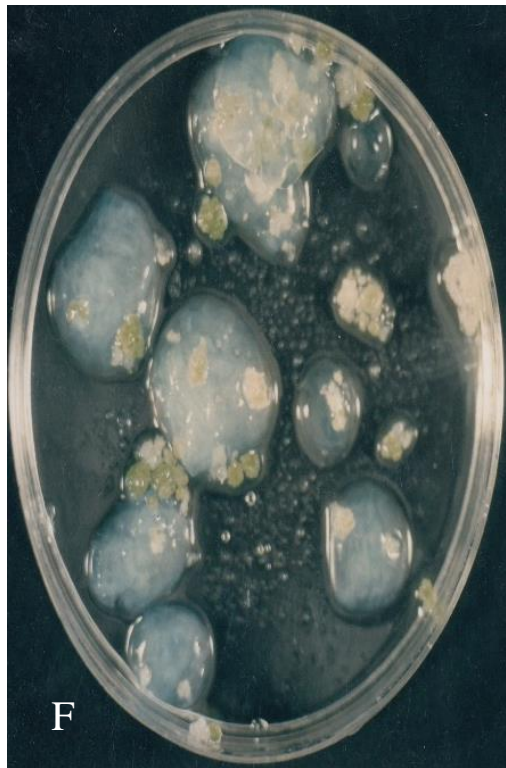

Callus from long term $35^{\circ} \mathrm{C} / 15 \mathrm{~min}$

Fig 1: Production of Callus from Culturing Cell Suspension derived from hypcotyles of Dianthus caryophyllus L. 


\section{Discussion}

Hypocotyle of Dianthus caryophyllus L. Was readily produced friable callus and this is due to the amenability of this explants in culture (21). Other kind of carnation explants also derived calli easily using suitable auxine and cytokinne in MS medium such as in leaves $(22,23)$.

Cell suspension cultured by embedding in agar behaved normally in its growth, division and forming colonies which developed to calli primordia. This is may attributed to the viability of heat treated cell that unaffected (24). Other investigator using the same heat treatment with sunflower cell suspension note the same pointes (18). In this study, generally heat treatment stimulate the division process of cells. This is may due to the increasing of cell wall permeability (25) or to the enhancement of synthesis of specific protein named HSP (Heat Shock Protein) and other phenolic compounds in cell suspension of carnation (26). Which sustained division of cells as in rice (27). Other studies reported that heat treatments permitted some ions like cupper sulphate to inter into cell which accelerate cell division (28). The only exception in this study is the treatments $50^{\circ} \mathrm{C} / 20$ which reduce the production of primordia compared with other treatment. This is probably due to the cease of cell dividing which is caused by damage the wall of cells firstly and proteins secondly (29).

\section{References}

1. Morgan R.W. ; Christman M. ; Jacobson, F.S., and Storz, G., (1986). Proc. Nat. Acad. Sci., USA. 83: 8059-8063.

2. Davidson, J.F. ; Whyte, B. ; Bissinger, P.H., and Schetl, R.H., (1996). Proc. Nat. Acad. Sci., USA, 93: 5116-5121.

3. Heidelberg, M.S., (2004). Biomedical and life Science 266: 4615-4620.

4. Gong, M. ; Li, Y.J. and Chens, Z., (1998). J. Plant Physiol. 153: 488-496.

5. Saltveit, M.E., Perser G., and Rab, A., (2004). J. Plant Physio. 76: 316-322.

6. Hwang, C.H., and Zimmerman, C.L., (1989). Plant Physiol.. 91: 552-558.

7. Nover, L. Scharf, K., and Neumann,D., (1983). Molecular and Cellular. Biol. 20: 1648-1655.

8. Al-Obedi, W.S., (2005). M.Sc. Thesis, Education College. Mosul Univ.

9. Monory, A.F. ; Farhan, S., and Dhindsa, R.S., (1993). Plant Physiol. 102: 1227-1235.

10. Scharf, K.D., and Nover, L., (2004). Cell culture. 30: 427-437.

11. Murashige, T., and Skoog, F., (1962). Physiol. Plant. 15: 473-497.

12. Mosopnera, T. , Rodriquez, L.E. ; Parra, A. and Rodriguez, M., (1992). Isha Acta Horticulturae. 48: 322-330.

13. Telma, K.H. ; Adonis, M. ; Antonio, F.D. ; Campos, A. and Murilo, M., (2002). Braz. Sci. Agric., 5 : 319-32.

14. Roper, W., (1979). Z. Pflanzenphysiol. 93: 245-257. 
15. Kanai, R., and Edwards, G.E., (2002). Plant Physiol. 52: 84-90.

16. Birkenhead, K., and Willmer, C.M., (1986). J. Exp. Bot. 37: 119-128.

17. AL-Mallah, M.K. and Zeadan ,S. M.(2006). J. AL-Rafidain Journal of Science .17: 126-138.

18. Rasheed, J.H. and Al-Obedi, W.S., (2006). Mesopotamia Journal of Agric.34: 22-28.

19. Dixon, R.A., (1985). Plant Cell Culture A Practical Approach. IRL Press, Oxford, Washington DC.

20. Rasheed, J.H., (2002). Ph.D. Thesis, Univ. of Mosul, Iraq.

21. Thakur, M., Sharma, D.R., and Sharma, S.K., (2002). Plant Cell Repts.. 20: 825-828.

22. Engvild, K.C., (1972). Physiol. Plant. 26: 62-66.

23. Thompson, J. A:, Abdulla ,R,C. and .Grartland ,K.M.(1989). J. Plant Physiol . 127:367-370

24. Mita ,G .:Nocco, G :Lenci , G.V. and Perotta ,C.(1997). Plant Cell Repts. $16: 792-796$

25. Gupta, H.S. ; Rech, E.L. ; Cocking, E.C., and Davey M.R., (1988). Plant Physiol. 133: 437-440.

26. Erich, F., Elstner, W., Obwald, R., and Volpert, H., (2002). Acta Horticult. 177:67-80.

27. Thompson, J.A., Abdullah, R., Chen, W.H., and Gartland, K.M., (1989). J. Plant Physiol. 127: 367-370.

28. Springer, N., (1991). J. Plant Physiol. 16: 1573-1581.

29. Orvar, B.L. ; Sangwan, V., Omann, F., and Dhindsa, R.S., (2000). Plant J. 23: 785-794. 